URL: https://www.justsecurity.org/69407/cyber-attacks-against-hospitals-and-thecovid-19-pandemic-how-strong-are-international-law-protections/

5. Naveen G. (2020). Failed Cyber Attack on Paris Hospital Authority // Cybersecurity Insiders. URL: https://www.cybersecurity-insiders.com/failed-cyberattack-on-paris-hospital-authority/

6. Schoolboy hacks into city`s tram system. URL: https://www.telegraph.co.uk/ news/worldnews/1575293/Schoolboy-hacks-into-citys-tram-system.html

7. UK rail network hit by multiple cyber attacks last year. URL: $\quad$ http://www.telegraph.co.uk/technology/2016/07/12/uk-rail-network-hit-bymultiple-cyber-attacks-last-year/

8. Schmitt, M. (2017). Tallinn Manual 2.0 on the International Law Applicable to Cyber Operations (2nd ed.). Cambridge: Cambridge University Press.

9. Zerologon Vulnerability: Analysis and Detection Tools by Igor Kovalenko \& Itamar Meydoni. URL: https://www.cynet.com/zerologon/

\title{
LOCAL GOVERNMENT REFORM IN UKRAINE: CURRENT STATE AND PROBLEMS
}

\section{Vladislav Oliinyk ${ }^{1}$}

\section{DOI: https://doi.org/10.30525/978-9934-26-002-5-33}

The start of the reform of local self-government in Ukraine was given after the approval by the government on April 1, 2014 of the Concept of Reforming Local Self-Government and Organization of Power in Ukraine. It was based on the provisions of the European Charter of Local Self-Government, which was ratified by the Verkhovna Rada on July 15, 1997. The implementation of the provisions of the document began in 2015 and provided for the consistent solution of the following tasks:

- Determine the territorial basis for the organization of local selfgovernment and executive power. levels.

- To delimit powers between local self-government bodies of various

- To delimit powers between local self-government and executive power.

- Determine the required amount of resources for each level of government.

- Establish the responsibility of local self-government bodies to the voter and the state.

The goal of the reform of local self-government is the transfer of significant powers from the executive authorities to the level of local self-

${ }^{1}$ Academy the State Penitentiary Service, Ukraine 
government. As part of this, it is planned to create new territorial entities united territorial communities, which will be provided with greater financial and administrative independence [1].

The Concept, which was supported by the Verkhovna Rada of Ukraine, assumed the reform of local self-government in several stages.

At the first preparatory stage (2014), a regulatory and legal framework (including amendments to the Constitution of Ukraine) should be adopted, which will lay the foundations and prescribe mechanisms for the formation of a new organization of local self-government, direct democracy and revision of the administrative-territorial structure.

After the adoption of the relevant regulatory framework, in 2015, the voluntary formation of united territorial communities began, which took place unevenly across the territory of Ukraine.

Some regions are distinguished by the rapid formation of territorial communities (Zaporozhye, Chernigov oblasts), and some are in no hurry to approve long-term plans of potential entities (Transcarpathian oblast).

According to the methodology and principles of the formation of new administrative units, communities can be created both from one old municipality, or from several. During the reform period, the average number of old municipalities that became part of a new community was 4.6. The Soviet model of management and territorial division showed its inconsistency with the real state of affairs in rural and urban communities, since the network of administrative-territorial division was simplified by means of its enlargement [2, p. 66-73].

In addition to rural areas, the unification of communities takes place in cities of regional significance. As of January 1, 2020, 27 cities of regional significance have formed territorial communities, which include 64 municipalities. More than 50 cities are included in the long-term plans of unification in the regions, approved by the Cabinet of Ministers of Ukraine [3].

After the formation of the united territorial communities, by the decision of the Central Election Commission of Ukraine, elections of deputies and heads of territorial communities are appointed in the new formation. In the first phase of the reform, elections were held in October 2015 in 159 communities.

In addition to the election of deputies and chairmen, each settlement (chief's district) has the opportunity to elect a chief who will be responsible for solving local problems of the village. However, the institution of chiefs is just being formed.

Reform of local government in the context of political and socio-economic instability has a number of advantages and disadvantages that need to be addressed. 
The positive results of the local government reform include:

- Institutional changes (the development of direct democracy through the voluntary formation of united territorial communities, the creation of an institution of local leaders - chiefs who are able to solve local problems without contacting higher authorities, et. al.).

- Financial successes (reducing costs by eliminating the overlapping competence of officials, increasing the level of profitability of local authorities, stimulating the development of territories by transferring part of taxes and subventions to the local level).

- Legal changes (creation of a regulatory and legal framework regulating the processes of reform of local self-government, the functioning of new entities and their relationships, amending the Constitution and acts that are close to the real state of affairs).

- Bureaucratic changes (transfer of a number of powers to local authorities, unification and standardization of administrative services for the population).

Already at the first stages of the reform, significant shortcomings are noticeable, which hinder the implementation of reforms in the field of forming a new power structure.

The main thing is the vulnerability and imperfection of the existing regulatory framework. This is both the slowness of the adoption of amendments to the current legislation (including the Constitution), and the lack of regulation of administrative competence and procedures for interaction between the old (state administrations) and new (communities) local authorities, as well as unresolved problems of the optimal structure of local self-government bodies, functioning electoral system, et. al. [4, p. 85-89].

The procedure for the distribution of financial assistance between communities and local councils, which continue to exist, remains important: the issues of their relationship in the financial sphere have not been resolved, mechanisms for the optimal distribution of subventions between communities according to their size (population size, area) have not been developed, and financial assistance to newly created communities for their integration into a new territorial structure, which is associated with additional costs in educational, medical, transport and other areas.

To organize effective local self-government and develop the institution of local initiative, state bodies need to consider the possibilities of training qualified personnel for new territorial authorities. It is also necessary to put in place the institution of rotation of power on the ground in order to exclude the possibility of the emergence of permanent «authoritarian regimes» in individual territories. 
In the post-Soviet space, local self-government is viewed as an institution of public power and is formed by state power from above, and this is the paradox. In Ukraine, on the contrary, an attempt was made to form a local initiative through the voluntary organization of local self-government bodies.

It is too early to talk about the success or failure of this attempt, since the reform of the vertical of power and the legal framework regarding direct democracy continues.

\section{References:}

1. On approval of the Concept of reforming local self-government and territorial organization of power in Ukraine 2014. Retrieved from: http://zakon2.rada.gov.ua/ laws/show/333-2014-\%D1\%80\#n8 (accessed 28 September 2020).

2. Drohomyretska, L. V. (2018). Stalyj rozvytok silskyx terytorialnyx gromad: teoretychni aspekty [Sustainable development of rural territorial communities: theoretical aspects]. Balanced nature management, no. 3, pp. 66-73.

3. State Register of Voters. Official website. Retrieved from: https://is.gd/JFp1Gq (accessed 28 September 2020).

4. Vatamaniuk-Zelenska, U. Z., \& Fikovska, M. Y. (2018). Yevropejskyj dosvid reform miscevogo samovryaduvannya [European experience of local self-government reforms]. Business Inform, no. 3(482), pp. 85-89.

\section{REGARDING THE ISSUE OF CORRECTING ERRORS IN COURT DECISIONS (CRIMINAL PROCEDURAL ASPECT)}

\section{Davyd Simonovych ${ }^{1}$}

DOI: https://doi.org/10.30525/978-9934-26-002-5-34

Criminal procedural activity of the court related to the execution of court decisions perhaps is the least studied issue in the theory of criminal procedure. The complexity of studying this activity lies in the multi-element aspect of the subject matter of executing court decisions stage, one of which is the activity of the court to resolve issues on various doubts and contradictions in court decisions. There has been a debate among scholars for decades in regard to the court activity on eliminating doubts and contradictions that arise during the execution of the sentence. Debatable issues were not resolved in the current Criminal Procedural Code of 2012, since the legislator did not provide a clear definition of «doubts and contradictions». A certain step towards

\footnotetext{
${ }^{1}$ Kharkiv National University of Internal Affairs, Ukraine
} 